\title{
INFLUENCE OF LEADERSHIP, REMUNERATION AND Organizational CUlTuRE ON HEALTh MADANi Trough PERFORMANCE OF PUBLIC HOSPITAL AS MEDIATOR
}

\author{
Faculty Of Medicine \\ University Of Batam \\ Indonesia \\ anafaizah@univbatam.ac.id
}

Faculty Of Engineering

University Of Batam

Indonesia

nurhatisyah@univbatam.ac.id

Faculty Of Economic

University Of Batam

Indonesia

sri.yanti@univbatam.ac.id

Faculty Of Economic

University Of Batam

Indonesia

nollapuspitadewi@univbatam.ac.id

\section{Chablullah Wibisono}

Faculty Of Economic

University Of Batam

Indonesia

chablullahwibisono@univbatam.ac.id

*Corrosponding author's Email: anafaizah@univbatam.ac.id

Peer-review under responsibility of 5th ${ }^{d}$ Asia International Conference 2019 Scientific Committee http://connectingasia.org/scientific-committee/

(C) 2019 Published by Readers Insight Publisher, lat 306 Savoy Residencia, Block 3 F11/1,44000 Islamabad. Pakistan,

editor@readersinsight.net

This is an open access article under the CC BY-NC-ND license (http://creativecommons.org/licenses/by-nc-nd/4.0/). 


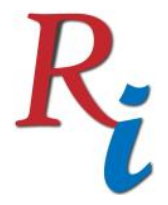

Asia Proceedings of Social Sciences

(APSS)

www.readersinsight.net/APSS

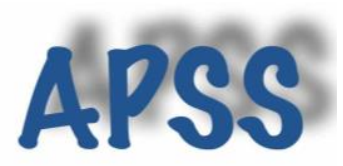

\section{A b s t r a c t}

Health of Madani or Civil Society is "Healthy, Self-reliant and Equitable People". The hospital as the spearhead of the leading health care services, whereas there are two kind of hospital in Batam, Public and Private Hospital. Orientation performance of hospitals is certainly influenced by the spirit and variable determiner of the hospital's performance, so this study aims to: "analyse of Leadership, Remuneration and Organizational Culture on Health Madani through Performance of Public Hospital”. The study population was all over the State Civil Administration, with a random sampling technique as the sample population, totally 220 respondents. The data were analyzed using SEM. The software used for the structural analysis is AMOS, and for a descriptive study using SPSS version 24.0. The research proves that: Leadership, Remuneration and Organizational Culture on Health Madani through Performance of Public Hospital as Mediator has significant effect. Pursuant to the result of this study is suggested that management of hospital in order to have a spirit of service as health care does not only embed oriented profit, the government also suggested to provide subsidized financing to hospital, so that health Madani which is "Healthy, Self-reliant and Equitable People" can be reached.

\section{Rese a r ch H igh I ight s}

The results highlights of this research:

1. What is the Influence of Leadership on Performance of Public Hospital?

2. What is the Influence of Remuneration on Performance of Public Hospital?

3. What is the Influence of Organizational Culture on Performance of Public Hospital?

4. What is the Influence of Leadership on Health of Madani?

5. What is the Influence of Remuneration on Health of Madani?

6. What is the Influence of Organizational Cultural on Health of Madani?

7. How are Leadership, Remuneration and Organizational Culture on Health Madani through Performance of Public Hospital? 


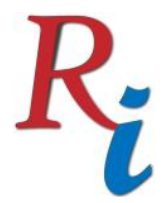

\section{Asia Proceedings of Social Sciences}

(APSS)

www.readersinsight.net/APSS

\section{Graphic a I A bstract}

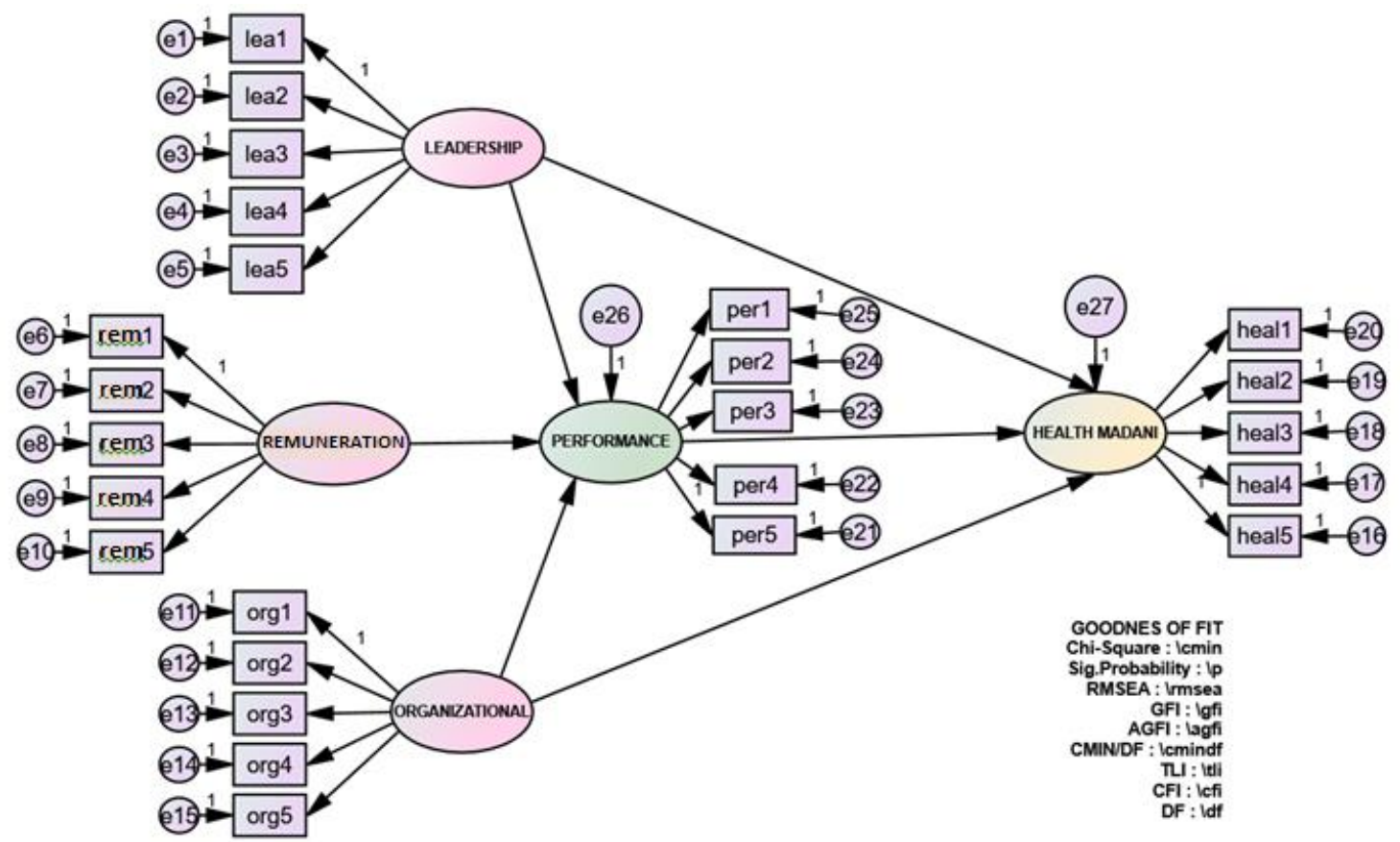

Fig. 1. Research Model of Leadership, Remuneration and Organizational Culture on Health Madani through Performance of Public Hospital as Mediator

\section{Research Objectives}

The research aims of this research:

1. To determine of the Influence of Leadership on Performance of Public Hospital.

2. To determine of the Influence of Remuneration on Performance of Public Hospital.

3. To determine of the Influence of Organizational Culture on Performance of Public Hospital.

4. To determine of the Influence of Leadership on Health of Madani.

5. To determine of the Influence of Remuneration on Health of Madani.

6. To determine of the Influence of Organizational Cultural on Health of Madani.

7. To analyse of Leadership, Remuneration and Organizational Culture on Health Madani through Performance of Public Hospital. 


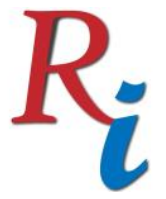

Asia Proceedings of Social Sciences

(APSS)

www.readersinsight.net/APSS

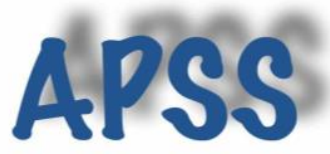

\section{Methodology}

The population is a collection of the whole object to be measured in the research (Cooper \& Schindler, 2003). The study population was all over the State Civil Administration, totally 490 with a random sampling technique as the sample population (Black \& DJ., 2001). Sample, according to (Sugiyono, 2014), is part of the number and features possessed by this population. In this research, the sample size adapted to the analysis. Base on the calculation results of Slovin's formula with limit error 5\%, so the samples were at 220.22 which is rounded to 220 . Thus, the sample used in the study is totally 220 respondents. The data were analyzed using Structural Equation Model (SEM). The software used for the structural analysis is Analysis Moment of Structural (AMOS) version 24.0 of Arbuckle (Solimun, 2004), and for a descriptive study using SPSS (Ghozali, 2005) version 24.0.

The brief results can be seen that all indicators have standardized estimate latent variables (regression weight) in the form of loading factor or lamda $(\lambda i)>0.50$, the critical value $C R$ $>2.000$ and has a probability of less than $0.05(* * *)$. Thus it can be said that all indicators of the latent variable is valid significant, except leadership on performance and remuneration on health Madani has a probability of more than 0.05 (Solimun, 2004).

\section{Results}

The research proves that the influence of leadership on performance (Buchan, Thompson, \& O'May, 2000) of public hospital is not significant. Meanwhile the influence of remuneration (Braithwaite, et al., 2017) and organizational culture on performance of public hospital is significant. Furthermore the influence of leadership and organizational culture (Yukl, 2013) on health Madani is significant. Meanwhile the influence of remuneration on health Madani is not significant. Analyze of Leadership, Remuneration and Organizational Culture on Health Madani through Performance of Public Hospital is significant.

As shown on the result of this research, can be seen that squared multiple correlations of performance 0.663. It means that determination of leadership, remuneration and organizational culture as indicators on performance are $66.3 \%$ quietly high if compared with the others variables are 33.7\% apart from this research variable (Ferdinand, 2006). Meanwhile, that squared multiple correlations of health Madani 0.978. It means that determination of leadership, compensation and organizational culture as indicators on 


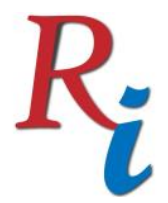

\section{Asia Proceedings of Social Sciences}

(APSS)

www.readersinsight.net/APSS

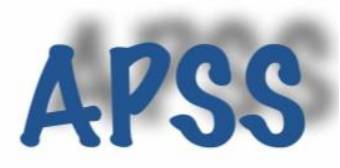

performance are $97.8 \%$ quietly high if compared with the others variables are $2.2 \%$ apart from this research variable (Ferdinand, 2006).

\section{Findings}

The results of this study encourage and provokes subsequent research in the field of human resources especially leadership, remuneration, organizational culture and performance of health Madani. Furthermore, most of the investigations needed base on in depth-qualitative approach (Hair, RE., RL., \& WC., 1998). Leaders and civil servants of public hospitals need to integrate the bureaucratic-based employee organizational culture with those who formulate and decide public policy based on politics (Basu, Andrews, KIshore, Panjabi, \& Stuckler, 2012). The remuneration and organizational culture on health Madani through the performance of hospitals significantly effect. For this reason, the KARS Accreditation system needs to be improved by increasing the indicator of assessment (Prybil, Levey, Killian, D., \& Roach, 2012).

\section{References}

Basu, S., Andrews, J., KIshore, S., Panjabi, R., \& Stuckler, D. (2012). Comparative Performance of Private and Public Healthcare System in Low- and Middle-Income Countries: A Systematic Review. Open Journal of PLoS Medicine, 9, 6.

Black, J., \& DJ., C. (2001). Methods and Problems of Social Research. Bandung: Refika Aditama.

Braithwaite, J., Hibbert, P., Blakely, B., Plumb, J., Hannaford, N., Cameron, J., et al. (2017).

Health System Framework and Performance Indicators in Eight Countries: A Comparative International Analysis. SAGE Open Medicine, 5, 1-10.

Buchan, J., Thompson, M., \& O'May, F. (2000). Health Workforce Incentive and Renumeration. Geneva: (C) World Health Organization.

Cooper, R. D., \& Schindler, a. P. (2003). Business Research Methods (8th ed.). New York: Mc. Graw-Hill.

Ferdinand. (2006). Methods of Management Research. Semarang: BP. UNIDIP.

Ghozali, I. (2005). Application of multivariate analysis using SPSS. Semarang: Diponegoro University Publishers Agency. 


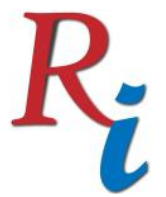

\section{Asia Proceedings of Social Sciences}

(APSS)

www.readersinsight.net/APSS

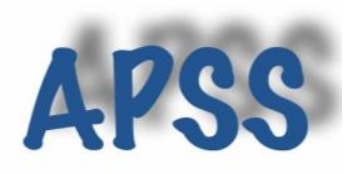

Hair, J. J., RE., A., RL., T., \& WC., B. (1998). Multivariate Analysis of The Data. New Jersey: Prentice Hall, Inc.

Prybil, L., Levey, S., Killian, R., D., B., \& Roach, W. (2012). Governance in Large Nonprofit Health Systems: Current Profile and Emerging Patterns. Lexington: Commonwealth Center for Governance Studies.

Solimun. (2004). Public Lecture Material Preparation and Use of SEM through AMOS Operations in Research. Denpasar: Study Program Master of Management Undiknas Denpasar.

Sugiyono. (2014). Quantitative Research Method, Qualitative and Combined (Mix Methods). Bandung: Alfabeta.

Yukl, S. (2013). Leadership in Organizations (8th Edition ed.). England: Pearson Education Limited.

Author's Biography

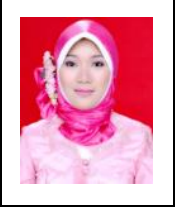

Full Name : Ns. Ana Faizah, S.Kep., M.Biomed.

NIDN / Rank Lecturer: 1007048401 / Assistant Professor

Place / Date of Birth: Sidoarjo April 4, 1984

Gender : Female

Marital Status: Married, Husband Name: Mr. Dheny C. Mirastyo

Address: Griya KDA Jl. Manyar 2 No.5 Batam Centre, Indonesia.

Mobile Phone: +6281333456704Ｅmail:anafaizah@univbatam.com

Current Job: Secretary of Rector, Lecturer in Nursing Department

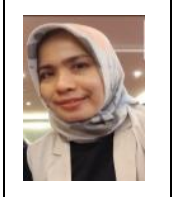

Full Name : Nurhatisyah, ST., STT., M.Kom

NIDN / Rank Lecturer: 0001087007 / Assoc. Professor

Place / Date of Birth: Padang, 01 August 1970

Gender : Female Marital Status: Married, Husband Name: Indra Sofany, ST,. MH

Address: Komplek Puri Legenda Blok B.09 No 12A Batam Center Batam, Indonesia.

Mobile phone:08126628289_Email: nurhatisyah@univbatam.ac.id

Current job : Lecturer S1 Faculty of Engineering in UNIBA, 


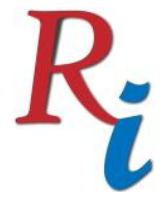

\section{Asia Proceedings of Social Sciences}

(APSS)

www.readersinsight.net/APSS
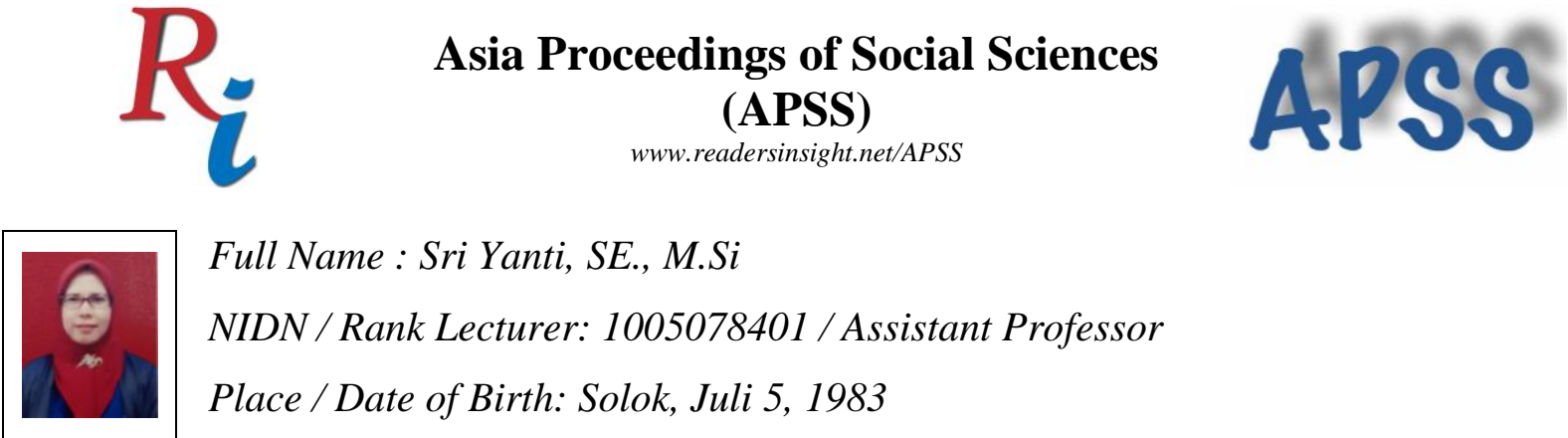

Full Name : Sri Yanti, SE., M.Si

NIDN / Rank Lecturer: 1005078401 / Assistant Professor

Place / Date of Birth: Solok, Juli 5, 1983

Gender : Female

Phone office: 07787485055

Address: Cluster City Garden Tulip 6 No 3 . Batam Centre, Indonesia.

Mobile Phone: +6282174044438 ,Email: sri.yanti@univbatam.com

Current Job: Head of Study Lecturer in Economics Department

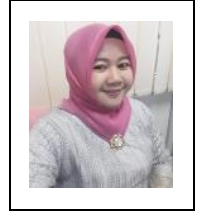

Full Name : Nolla Puspita Dewi, SE., M.Ak.

NIDN / Rank Lecturer: 1023028302 / Assistant Professor

Place / Date of Birth: LB.Ambacang February 23, 1983

Gender: Female Marital Status: Married, Husband Name: Mr. Khairuddin Siregar Address: Marbella Residance D6 No.11 Batam Centre, Indonesia Mobile Phone: +6281270169383, Email: nollapuspitadewi@univbatam.com Current Job: Head of study Lecturer in Economics Department.

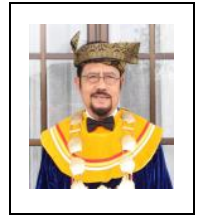

Full Name : Prof. Dr. Ir. H. Chablullah Wibisono, MM.

Place / Date of Birth: Kendal, 10 November 1953

Gender: Male: $\quad$ Marital Status: Married $\quad$ Wife Name: Hj. Ani Yuana

Address: Jl. Kartini V No. 50 Sei Harapan Sekupang Batam,

Mobile phone:0811700503Ｅmail: chablullahwibisono@gmail.com

Current job: Rector UNIBA, Lecturer S1 and S2 in UNIBA. 